\title{
Scientific Literacy Ability of Junior High School Students on Static Electricity and Electricity in Living Things
}

\author{
Moh. Shohib ${ }^{1}$, Yuni Sri Rahayu' ${ }^{2}$, Wasis ${ }^{3}$, Eko Hariyono ${ }^{4}$ \\ 1,2,3,4Universitas Negeri Surabaya, Surabaya, Indonesia
}

\begin{tabular}{|c|c|}
\hline (A) Check for updates open access cc) (i) (2) & DOI: https://doi.org/10.46245/ijorer.v2i6.170 \\
\hline Sections Info & ABSTRACT \\
\hline Article history: & Junior high school students need to have good scientific literacy skills to have \\
\hline Submitted: October 31, 2021 & sufficient competence to compete in the current and future era of information \\
\hline Final Revised: November 17, 2021 & and globalization. Science is basic knowledge covering products, processes, \\
\hline November 28, 2021 & and applications. One of the science materials is static electricity and \\
\hline r 30, 2021 & electricity in living things. This study aimed to determine the literacy profile \\
\hline Kata Ku & of junior high school students on static electricity and electricity in living \\
\hline Des & things. The subjects of this study were junior high school students. This \\
\hline Scienti & research uses a descriptive research method. Data collection instruments \\
\hline Literacy Ability & consist of scientific literacy instruments. The results showed that junior high \\
\hline 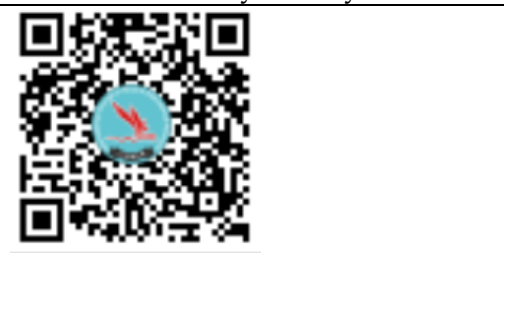 & $\begin{array}{l}\text { school students' average scientific literacy ability on static electricity and } \\
\text { electricity in living things, in general, was low criteria. The achievement of } \\
\text { scientific literacy ability in the first indicator to explain scientific phenomena } \\
\text { obtained a score of } 28.76 \% \text { higher when compared to the second indicator } \\
\text { evaluating and designing scientific investigations to obtain a score of } 15.73 \% \text {, } \\
\text { while the third indicator to interpret data and scientific evidence obtained } \\
\text { the lowest average score. of } 10.13 \% \text {. In general, the criteria for scientific } \\
\text { literacy in all indicators are very low. }\end{array}$ \\
\hline
\end{tabular}

\section{INTRODUCTION}

Education has a significant role in preparing the next generation who will maintain the survival of a nation and state. Education can be obtained formally and non-formally. Formal education is education obtained through learning carried out in schools. Education in schools must equip students with the skills and competencies needed to

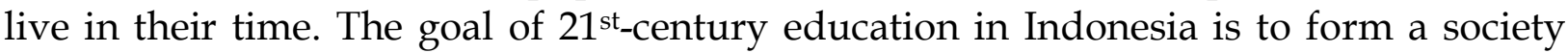
with independent, willing, and capable individuals to create a happy, prosperous, and able to compete globally (Mardianti et al., 2020). The purpose of science education is to increase students' competence to meet their needs in various situations and conditions (Rewalino et al., 2020; Rini et al., 2021). With these competencies, students will have the ability to study further and live in a society in the 21st century. 21st-century abilities include the 4Cs, namely Creativity, Critical Thinking, Collaboration, and Communication (Zubaidah, 2018; Mijaya et al., 2019). One of the higher-order thinking skills that students need to have is scientific literacy skills. Science is a basic knowledge that includes products, processes, and applications (Retnowati et al., 2021). One of the materials contained in the 9 th-grade science learning is static electricity and electricity in living things.

The Ministry of Education and Culture has released the results of the 2018 PISA study, which was attended by 79 countries. The scientific literacy ability of students in Indonesia scores 396, still far from the OECD average standard of 489 (Ain and Mitarlis, 2020). Scientific literacy is defined as an individual's ability to devote attention to science-related topics and scientific ideas as a form of individual reflection 
(Kemendikbud, 2019). Scientific literacy skills will guide students to apply the science they have learned as a basis when making decisions in today's life which are influenced by the development of science and technology (Prasetya et al., 2019). Someone who is scientifically literate will always pay attention to logical debates about science and technology that require competence to explain a phenomenon scientifically, evaluate and design scientific questions, and interpret data and evidence scientifically as well.

Holbrook and Ramnikmae in Wasis et al. (2020) stated two general views about scientific literacy, namely science literacy and scientific literacy (Wasil et al., 2020). Group Science literacy and scientific literacy have a different notions of the meaning of scientific literacy. The group science literacy assumes that science content is a fundamental and fundamental component in scientific literacy. A person is said to be scientifically literate if that person knows science. Scientific literacy in this group is more likely to be limited to understanding scientific words or terms. Meanwhile, the group is of the scientific literacy view that scientific literacy is literate in science content and how science is used to adapt to the rapid changes of life. Scientific literacy, according to the statement of the second group, is in line with life skills.

NSES (National Science Education Standards) (1996) in its description has focused on scientific literacy in the context of Natural Science (IPA) or science which includes living things and life processes, physical sciences, chemistry, as well as the earth and the universe (Wasil et al., 2020). Therefore scientific literacy, according to NSES, is defined as scientific literacy that describes a person's knowledge and understanding of scientific concepts and processes needed to make decisions, participate in social and cultural life, and participate in economic growth.

According to NCES (National Center For Education Statistics) (2012), scientific literacy is knowledge and understanding of scientific concepts and processes needed in making personal decisions, contributing to cultural and social activities, and economic productivity (Samsu et al., 2020). Science literacy should be mastered by students related to how students care about the environment, health, economy, social and technological problems, and the progress and development of science (Handayani et al., 2020). Scientific literacy is critical to solving various ethics, morals, and global issues due to rapid changes in science and technology (Jamaluddin et al., 2019).

OECD (Organization for Economic Cooperation and Development) explains that scientific literacy is divided into four interrelated aspects, namely aspects of knowledge (Knowledge), competence (Competencies), context (Contexts), and attitudes of science (Attitudes) (Anggraeni et al., 2020; Wulandari and Sholihin, 2016). Aspects of knowledge in scientific literacy include content knowledge, procedural knowledge, and epistemic knowledge. Factors of scientific literacy competence include explaining phenomena scientifically, evaluating and designing scientific investigations, and interpreting data and evidence scientifically (Hufri et al., 2019). Context aspects of scientific literacy include personal, local, and global contexts (Rini et al., 2021). While the attitude aspect of scientific literacy is related to the question of what is considered valuable by a person (ethical competence), moral competence includes human rights, tolerance, education for peace, gender equality, and efforts to build a society that has a sense of responsibility (responsible citizen). The link between the four aspects of scientific literacy is how scientific knowledge and competence can be implemented in various contexts to foster a wise attitude. Wasis et al. (2020) stated that scientific literacy is an integration between the domains of attitudes, skills, and knowledge, therefore in 
general scientific literacy can be defined as a person's ability to understand science, then apply it in real life so that he can behave wisely both as a person and as a person. Community members (Wasis, 2020). Based on this description, students must have scientific literacy skills in facing the era of development in the 21st century. This study aims to describe the profile of scientific literacy abilities of Junior High School students on static electricity and electricity in living things.

\section{RESEARCH METHOD}

The type of research is a quantitative descriptive study using a survey method. The data generated uses test results data that describe Junior High School students' scientific literacy test results on static electricity and electricity in living things. The flow of the research carried out is shown in the following Figure 1.

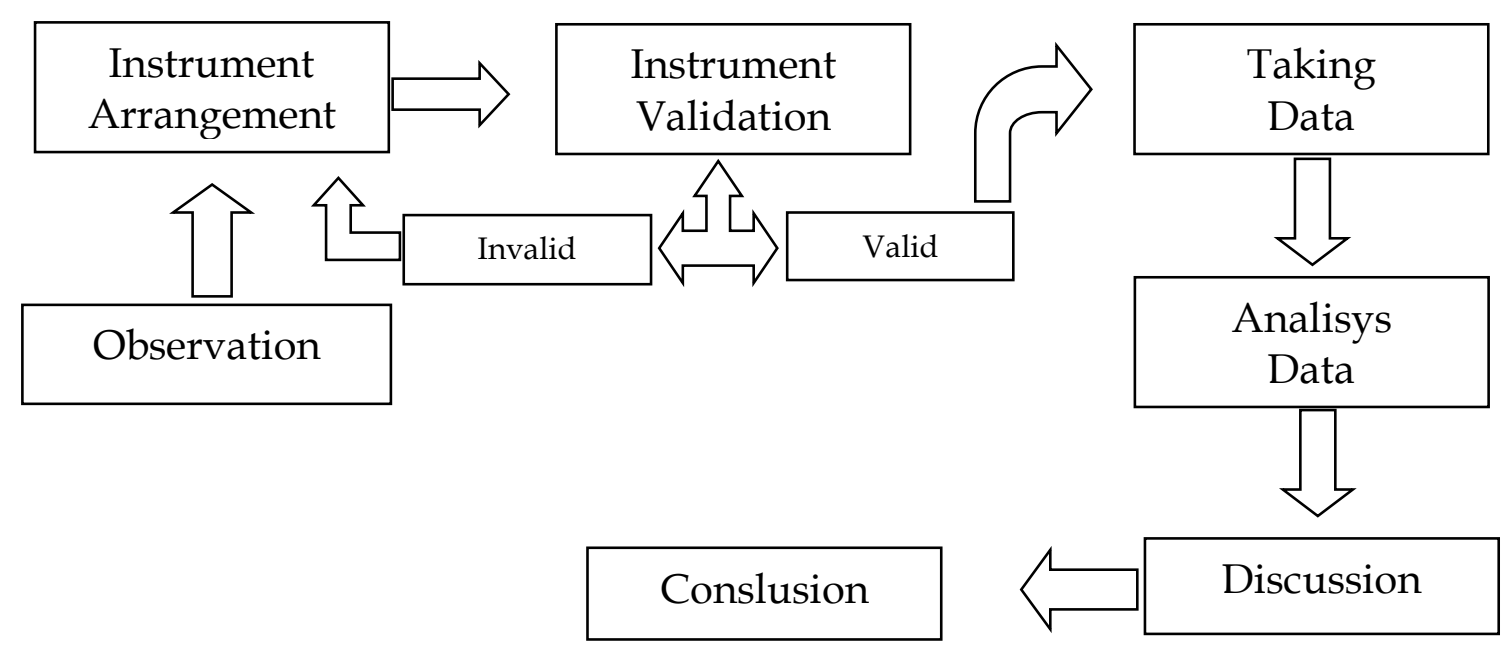

Figure 1: The research flow.

The population of this study were 9th-grade students of State 1st Junior High School of Tambakrejo in the 2021/2022 academic year, which consisted of 8 classes with each class having 32 students, so the total population research is 256 students. Determination of the research sample was carried out at random systematically with a full selection of 35 students.

The data collected is in the form of quantitative data from scientific literacy test results. Scientific literacy test instrument developed based on scientific literacy competency indicators. According to PISA, the scientific literacy competency indicator in this study refers to the scientific literacy competency indicator, which includes explaining phenomena scientifically, evaluating and designing scientific investigations, and interpreting data and evidence scientifically. The scientific literacy test instrument in this study used various questions, including multiple-choice, true-false, short entries, and descriptions. The question instrument for scientific literacy competency indicators to explain scientific phenomena consists of 8 questions, namely questions number $8,9,10,11,12,13,14$, and 15 . The question instrument for scientific literacy indicators evaluates and designs scientific investigations comprised of 4 questions, namely questions number 1, 2, 3, and 4. And the question instrument for scientific literacy indicators interpreting data and evidence scientifically consists of 3 questions, namely questions number 5, 6, and 7. The instrument questions used in this study were developed by researchers and validated by three validators consisting of 1 validator 
from the expert element and two validators from the practitioner element to test the validity of the construction. A test is said to have construction validity of the items that make up the test measure every aspect of thinking as stated in the Special Instructional Objectives. The specific instructional objectives referred to in this study are scientific literacy skills.

The quality of the instrument as a measuring tool to express the results as carefully as possible is assessed by the validity and reliability of the instrument. The validity and reliability test of the device was carried out using SPSS. The validity test helps determine the validity or suitability of the questions used to measure and obtain research data. Provisions that the instrument is declared valid and shows conformity if it meets the requirements according to the following Table 1.

Table 1. Basis of the decision on the validity of the instrument question.

\begin{tabular}{lc}
\hline \multicolumn{1}{c}{ Basis of decision } & Explanation \\
\hline $\mathrm{r}$ count $>$ r Table & Valid \\
Sig $<0,05$ dan positive value & Valid \\
\hline
\end{tabular}

The reliability test aims to see whether the instrument used has consistency if the measurement is repeated. According to Wiranata (2014), a question or questionnaire is reliable if the Cronbach alpha value is $>0.6$. The data analysis technique used in this study is the descriptive data analysis technique, namely, describing and summarizing the measurement data on the scientific literacy ability of Junior High School students who were the samples in this study. The scientific literacy score is calculated using the percentage technique per scientific literacy indicator, then the results obtained are interpreted using a Table of criteria as shown in Table 2.

Table 2: Criteria for scientific literacy scores.

\begin{tabular}{cc}
\hline Interval & Criteria \\
\hline $86 \%-100 \%$ & Very Good \\
$72 \%-85 \%$ & Good \\
$58 \%-71 \%$ & Enough \\
$43 \%-57 \%$ & Low \\
$\mathrm{N} \leq 43 \%$ & Very Low \\
\hline
\end{tabular}

\section{RESULTS AND DISCUSSION}

The test results data were tested for validity and reliability using SPSS. The validity tests conducted by expert validators and practitioners state that the questions developed are valid and can be used to measure scientific literacy skills on static electricity and electricity in living things. The validity and reliability test data with SPSS are presented in Table 3 and Table 4:

Table 3. Validity results with SPSS.

\begin{tabular}{cccc}
\hline Item & r-count & Sig & Explanation \\
\hline 1 & 0,516 & 0,002 & Valid \\
2 & 0,541 & 0,001 & Valid \\
3 & 0,677 & 0,000 & Valid \\
4 & $-0,380$ & 0,830 & Invalid \\
5 & 0,593 & 0,000 & Valid \\
6 & 0,139 & 0,434 & Invalid \\
7 & 0,499 & 0,003 & Valid \\
8 & 0,332 & 0,055 & Invalid \\
9 & 0,027 & 0,878 & Invalid \\
\hline
\end{tabular}


Table 4. Reability statistic with SPSS.

\begin{tabular}{ccc}
\hline Item & Cronbach alpha if item delete & Explanation \\
\hline 1 & 0,714 & Reliable \\
2 & 0,651 & Reliable \\
3 & 0,620 & Reliable \\
4 & 0,604 & Reliable \\
5 & 0,704 & Reliable \\
\hline
\end{tabular}

Reliability test results using SPSS obtained the effects that the questions were reliable with a coefficient value Cronbach alpha of 0.711 , meaning that the instrument is consistent if the measurements are repeated. Data on the scientific literacy ability of the students were collected using the device of science literacy questions. Based on the data obtained, the scientific literacy skills of students are presented in Table 5.

Table 5. Scientific literacy ability of junior high school students.

\begin{tabular}{|c|c|c|c|c|c|c|c|c|}
\hline \multirow{2}{*}{ Student } & \multicolumn{2}{|c|}{ Final score } & \multicolumn{2}{|c|}{$\begin{array}{c}\text { Score of scientific } \\
\text { literacy indicator } 1\end{array}$} & \multicolumn{2}{|c|}{$\begin{array}{c}\text { Score of scientific } \\
\text { literacy indicator } 2\end{array}$} & \multicolumn{2}{|c|}{$\begin{array}{l}\text { Score of scientific } \\
\text { literacy indicator } 3\end{array}$} \\
\hline & $\begin{array}{c}\text { Score } \\
(\%)\end{array}$ & Criteria & $\begin{array}{c}\text { Score } \\
(\%)\end{array}$ & Criteria & $\begin{array}{c}\text { Score } \\
(\%)\end{array}$ & Criteria & $\begin{array}{c}\text { Score } \\
(\%)\end{array}$ & Criteria \\
\hline Student 1 & 45,33 & $\mathrm{R}$ & 25 & SR & 65 & $\mathrm{C}$ & 73 & B \\
\hline Student 2 & 49,33 & $\mathrm{R}$ & 50 & $\mathrm{R}$ & 55 & $\mathrm{R}$ & 40 & SR \\
\hline Student 3 & 46,67 & $\mathrm{R}$ & 38 & SR & 70 & C & 40 & SR \\
\hline Student 4 & 57,33 & $\mathrm{R}$ & 50 & $\mathrm{R}$ & 65 & C & 67 & C \\
\hline Student 5 & 52 & $\mathrm{R}$ & 63 & C & 15 & SR & 73 & B \\
\hline Student 6 & 45,33 & $\mathrm{R}$ & 50 & $\mathrm{R}$ & 65 & C & 7 & SR \\
\hline Student 7 & 46,67 & $\mathrm{R}$ & 38 & SR & 45 & $\mathrm{R}$ & 73 & B \\
\hline Student 8 & 64 & C & 63 & C & 65 & C & 67 & C \\
\hline Student 8 & 54,67 & $\mathrm{R}$ & 63 & C & 50 & $\mathrm{R}$ & 40 & SR \\
\hline Student 10 & 64 & C & 63 & C & 65 & C & 67 & C \\
\hline Student 11 & 57,33 & $\mathrm{R}$ & 50 & $\mathrm{R}$ & 90 & SB & 33 & SR \\
\hline Student 12 & 64 & C & 63 & C & 65 & C & 67 & C \\
\hline Student 13 & 45,33 & $\mathrm{R}$ & 50 & $\mathrm{R}$ & 65 & C & 7 & SR \\
\hline Student 14 & 64 & C & 63 & C & 65 & C & 67 & C \\
\hline Student 15 & 52 & $\mathrm{R}$ & 50 & $\mathrm{R}$ & 65 & C & 40 & SR \\
\hline Student 16 & 64 & C & 63 & C & 65 & C & 67 & C \\
\hline Student 17 & 46,67 & $\mathrm{R}$ & 50 & $\mathrm{R}$ & 70 & C & 7 & SR \\
\hline Student 18 & 64 & C & 63 & C & 65 & C & 67 & C \\
\hline Student 19 & 52 & $\mathrm{R}$ & 63 & C & 65 & C & 7 & SR \\
\hline Student 20 & 50,67 & $\mathrm{R}$ & 50 & $\mathrm{R}$ & 40 & SR & 67 & C \\
\hline Student 21 & 52 & $\mathrm{R}$ & 63 & C & 40 & SR & 40 & SR \\
\hline Student 22 & 57,33 & $\mathrm{R}$ & 50 & $\mathrm{R}$ & 65 & C & 67 & C \\
\hline Student 23 & 45,33 & $\mathrm{R}$ & 50 & $\mathrm{R}$ & 40 & SR & 40 & SR \\
\hline Student 24 & 57,33 & $\mathrm{R}$ & 50 & $\mathrm{R}$ & 65 & $\mathrm{C}$ & 67 & $\mathrm{C}$ \\
\hline Student 25 & 52 & $\mathrm{R}$ & 63 & C & 65 & C & 7 & SR \\
\hline Student 26 & 64 & C & 63 & C & 65 & C & 67 & C \\
\hline Student 27 & 49,33 & $\mathrm{R}$ & 63 & C & 55 & $\mathrm{R}$ & 7 & SR \\
\hline Student 28 & 57,33 & $\mathrm{R}$ & 63 & C & 40 & SR & 67 & C \\
\hline Student 29 & 56 & $\mathrm{R}$ & 63 & C & 55 & $\mathrm{R}$ & 40 & SR \\
\hline Student 30 & 52 & $\mathrm{R}$ & 50 & $\mathrm{R}$ & 45 & $\mathrm{R}$ & 67 & C \\
\hline Student 31 & 48 & $\mathrm{R}$ & 38 & SR & 55 & $\mathrm{R}$ & 67 & C \\
\hline Student 32 & 50,67 & $\mathrm{R}$ & 50 & $\mathrm{R}$ & 40 & SR & 67 & C \\
\hline Student 33 & 65,33 & C & 50 & $\mathrm{R}$ & 95 & SB & 67 & C \\
\hline Student 34 & 53,33 & $\mathrm{R}$ & 50 & $\mathrm{R}$ & 50 & $\mathrm{R}$ & 67 & C \\
\hline Student 35 & 66,67 & C & 63 & C & 75 & B & 67 & C \\
\hline Total & 54,63 & $\mathbf{R}$ & 51 & $\mathbf{R}$ & 59 & $\mathrm{C}$ & 51 & $\mathbf{R}$ \\
\hline
\end{tabular}


Table 6. Data on scientific literacy ability per indicator.

\begin{tabular}{lcc}
\hline \multicolumn{1}{c}{ Indicator } & Score & Criteria \\
\hline Explaining phenomena scientifically. & 51 & $\mathrm{R}$ \\
Evaluating and designing scientific. & 59 & $\mathrm{C}$ \\
Scientifically interpreting data and evidence. & 51 & $\mathrm{R}$ \\
\hline
\end{tabular}

Information :

SB = Very Good; $\mathrm{B}=$ Good C= Enaough; R= Low ; dan SR= Very Low .

Based on the data in Table 5, the average score of the scientific literacy ability of students obtained a score of $54.63 \%$ with low criteria. Furthermore, an analysis was carried out for each scientific literacy indicator. The analysis was carried out on the acquisition of scores for each item of the question that showed each indicator of scientific literacy. Based on the data analysis, the average value of the scientific literacy ability of students per scientific literacy indicator is shown in Figure 2: It shows that students have low scientific literacy skills on static electricity and electricity in living things.

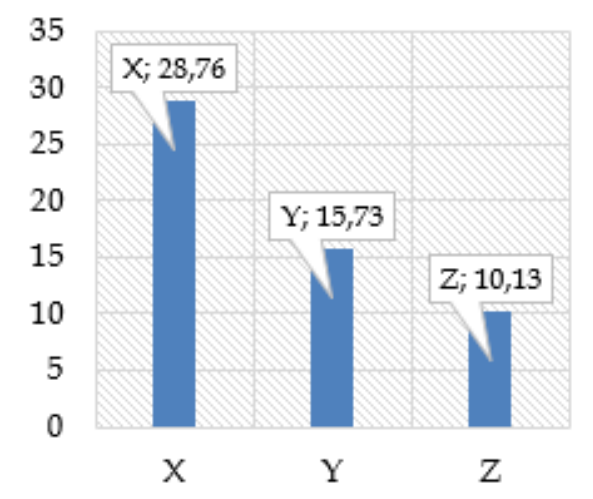

\author{
Information \\ $X=$ Explaining phenomena scientifically. \\ $\mathrm{Y}=$ Evaluating and designing scientific. \\ $\mathrm{Z}=$ Scientifically interpreting data and evidence
}

Figure 2. Data of science literacy ability per indicator.

Based on Figure 2, the average value of students' scientific literacy ability on the first indicator is higher when compared to the second and third indicators. The average score for the three indicators of scientific literacy, namely interpreting data and evidence scientifically, students obtained a score of $10.13 \%$ with very low criteria. The average score for the second indicator of scientific literacy, namely evaluating and designing scientific investigations, students obtained $15.73 \%$ with very low criteria. While the average score for the first indicator, students received a score of $28.76 \%$ with very low criteria. Based on the data in Figure 2, it can be concluded that the scientific literacy ability per scientific literacy indicator on static electricity and electricity in living things is still very low.

Students' low scientific literacy ability can be influenced by several factors, including selecting science learning models carried out by educators in building learning concepts (Agustina et al., 2020). The quality of the books used in learning (Merta et al., 2020) stated that the causes of the low scientific literacy skills of students include the learning process that is less supportive in developing scientific literacy skills and the lack of habituation of students in working on scientific literacy-oriented questions (Merta et al., 2020). 
Concerning the development of scientific literacy skills, contextual learning has similar characteristics, requiring the existence of a real-life context. The contextual learning approach emphasizes the link between classroom learning and real life. Scientific literacy skills need students to implement the knowledge and skills they have in everyday life. Wasis et al. (2020) stated that the characteristics of contextual learning emphasize the creation of a meaningful link between what is learned and its application in real life.

The Washington State Consortium for Contextual Teaching and Learning (2001) found that among the characteristics of contextual learning are inquiry and authentic assessment. Contextual learning has features, inquiry meaning that contextual learning takes a cycle consisting of observing, asking questions, analyzing, and formulating theories, both individually and in groups. In these activities, critical thinking skills are developed and used. While the characteristics of Authentic assessment in contextual learning are intended to focus on meaningful relationships with life, the learning assessment is not possible only to measure cognitive abilities. Still, it must be authentic, including product, process, and attitude dimensions as a whole. Therefore, the assessment involves tasks that are contextual and relevant to real-life problems.

Science learning can be done by applying several learning models to improve students' scientific literacy skills, including the guided inquiry learning model (Retnowati et al., 2021; Mardianti et al., 2020; Prasetya et al., 2019), learning model discovery learning. Wasis et al. (2020) stated that the PjBL and PBL learning models also facilitate students learning to overcome authentic problems or real-life problems. The stages or syntax in guided inquiry-based learning can encourage students to explore their knowledge so that students can become independent, active, and skilled individuals in solving problems based on the information and knowledge obtained (Widowati et al., 2018)

\section{CONCLUSION}

Based on the research results, the achievement of scientific literacy ability in the first indicator to explain scientific phenomena obtained a score higher when compared to the second indicator evaluating and designing scientific investigations, while the third indicator to interpret data and scientific evidence received the lowest average score. In general, the criteria for scientific literacy in all indicators are very low. There is an influence in the application of learning models, the quality of learning materials, and the assessment process on students' scientific literacy abilities. In the future, it is necessary to research the development of teaching materials based on guided inquiry learning models to improve the scientific literacy skills of junior high school students on static electricity and electricity in living things.

\section{REFERENCES}

Agustina, I. R., Andinasari., \& Lia, L. (2020). Kemampuan literasi sains pada materi zat melalui model pembelajaran inkuiri terbimbing berbantuan multimedia. JPF: Jurnal Pendidikan Fisika, 8(1), 1-10. http://doi.org/10.24127/jpf.v8i1.2491

Ain, Q., \& Mitarlis. (2020). Pengembangan lkpd berorientasi inkuiri terbimbing untuk meningkatkan literasi sains pada materi faktor-faktor yang mempengaruhi laju reaksi.
Unesa Journal of Chemical
Education,
9(3),
397-406.

https:// doi.org/10.26740/ujced.v9n3.p397-406 
Scientific Literacy Ability of Junior High School Students on Static Electricity and Electricity in Living Things

Anggraeni, A. Y., Wardani, S., \& Hidayah, A. N. (2020). Profil peningkatan kemampuan literasi kimia siswa melalui pembelajaran inkuiri terbimbing berbasis kontekstual. Jurnal Inovasi Pendidikan Kimia, 14(1), 2512-2523.

Handayani, M., Rusilowati, A., \& Sarwi. (2020). Pengembangan lembar kerja siswa berbasis literasi sains pada materi alat-alat optik untuk meningkatkan kemampuan literasi sains siswa SMP. UPEJ: Unnes Physics Education Journal, 9(1), 80-88. https://doi.org/10.15294/upej.v9i1.38284

Hufri, Hidayati, Afrizon, R., Deswita, D., Wahynuni, R., (2018). Validation analysis of physics teaching materials based on contextual through inquiry to increase student's science literacy. Journal of Physics: Conference Series, 1185(1), 1-11. https://doi.org/:10.1088/17426596/1185/1/012133

Jamaluddin, Jufris, A. W., Ramdani, A., \& Azizah, A. (2019). Profil literasi sains dan keterampilan berpikir kritis pendidik IPA SMP. Jurnal Penelitian Pendidikan IPA, 5(1),120130. https://doi.org/10.29303/jppipa.v5i1.185

Kemendikbud. (2019). Education in indonesia learns from the results of pisa 2018. Jakarta: Balitbang Kemendikbud.

Mardianti, F., Yulkifli, \& Asrizal. (2020). Metaanalisis pengaruh model pembelajaran inkuiri terhadap keterampilan proses sains dan literasi saintifik. Sainstek Jurnal Sains dan Teknologi, 12(2), 91-100. https:// doi.org/10.31958/js.v12i2.2435

Merta, I. W., Artayasa, I. P., Kusmiyati, Lestari, N., \& Setiadi, D. (2020). Profil literasi sains dan model pembelajaran dapat meningkatkan kemampuan literasi sains. Jurnal PIJAR MIPA, 15(3), 223-228. http://doi.org/10.29303/jpm.v15i3.1889

Mijaya, N. P. A. P., Sudiatmika, A. A. I. A. R., \& Selamet, K. (2019). Profil literasi sains siswa smp melalui model pembelajaran levels of inquiry. JPPSI: Jurnal Pendidikan dan Pembelajaran Sains Indonesia, 2(2), 161-171. http:/ / doi.org/10.23887/jppsi.v2i2.19385

Samsu, N., Mustika, D., Nafaida, R., \& Manurung, N. (2020). Analisis kelayakan dan kepraktisan modul praktikum berbasis literasi sains untuk pembelajaran IPA. Jurnal IPA $\mathcal{E}$ Pembelajaran IPA, 4(1), 29-40. https:// doi.org/10.24815/jipi.v4i1.15546

Prasetya, C., Ganis, A., \& Sulastri. (2019). Pengembangan lembar kerja peserta didik berbasis inkuiri terbimbing pada materi hidrolisis garam untuk meningkatkan literasi sains. Jurnal Pendidikan Sains Indonesia, 7(1), 34-41. https:/ / doi.org/10.24815/jpsi.v7i1.13556

Retnowati, F., Prabowo, \& Madlazim. (2021). Validitas perangkat pembelajaran model inkuiri terbimbing untuk melatihkan literasi sains siswa. Jurnal Education and Development, 9(1), 331-334.

Rewalino, Y. I., Supriyatman, \& Kade, A. Pengaruh model pembelajaran inkuiri terbimbing terhadap kemampuan literasi sains siswa. JPFT: Jurnal Pendidikan Fisika Tadulako Online, $8(3), 125-128$.

Rini, C. P., Hartantri, S. D., \& Amaliyah, A. (2021). Analisis kemampuan literasi sains pada aspek kompetensi mahasiswa PGSD FKIP universitas muhammadiyah Tangerang. Jurnal Pendidikan Dasar Nusantara, 6(2), 166-179. doi.org/10.29407/jpdn.v6i2.15320a

Wasis, Rahayu, S. Y., Sunarti, T., \& Indana, S. (2020). Hots dan literasi sains: Konsep, pembelajaran, dan penilaiannya. Jombang: Kun Fayakun.

Widowati, A., Anjarsari, P., Zuhdan, K. P., \& Dita, A. (2018). Applying innovative approach "Nature of Science (NoS) within inquiry" for developing scientific literacy in the student worksheet. Physics Journal. conf. Series 983(1), 1-7. https://doi.org/10.1088/17426596/983/1/012199.

Wulandari, N. \& Sholihin, H. (2016). Analisis kemampuan literasi sains pada aspek pengetahuan dan kompetensi sains siswa smp pada materi kalor. EDUSains, 8(1), 66-73. https://doi.org/10.15408/es.v8i1.1762

Zubaidah, S. (2018). Mengenal 4C: Learning and innovation skills untuk menghadapi era revolusi industri 4.0. Seminar 2nd Science Education National Conference, 2018(1), 1-19. 
Scientific Literacy Ability of Junior High School Students on Static Electricity and Electricity in Living Things

\author{
Moh. Shohib \\ Postgraduate of Natural Science Education Programme \\ State University Of Surabaya, \\ Kampus Lidah Wetan, Jalan Kampus Lidah Unesa, Surabaya 60213, Indonesia \\ Email: mohshohib.20026@mhs.unesa.ac.id
}

Yuni Sri Rahayu, Ph.D.

Departemen of Science, Postgraduate of Natural Science Education

State University Of Surabaya,

Kampus Lidah Wetan, Jalan Kampus Lidah Unesa, Surabaya 60213, Indonesia

Email: yunirahayu@unesa.ac.id

Prof. Dr. Wasis, M.Si.

Departemen of Science, Postgraduate of Natural Science Education

State University Of Surabaya,

Kampus Lidah Wetan, Jalan Kampus Lidah Unesa, Surabaya 60213, Indonesia

Email: wasis@unesa.ac.id

Dr. Eko Hariyono, M.Pd.

Departemen of Science, Postgraduate of Natural Science Education

State University Of Surabaya,

Kampus Lidah Wetan, Jalan Kampus Lidah Unesa, Surabaya 60213, Indonesia

Email: ekohariyono@unesa.ac.id 